England), and that they encourage trade with low duties; from the fashion of their ships, Boyers, Hoybarks, and Hoyes, which are continually freighted before the English "by reason of their few Marriners, and great bulke, serving the Merchant cheap; their forwardnesse to further all manner of trading; and their wonderfull imployment of Busses for fishing." The Dutch were the first free traders, anticipating the English by about two centuries. In Raleigh's time, a ship laden with three hundred tons of wine from Bordeaux could clear in Holland for fifty pounds, but in England the duty was nine hundred pounds.

Raleigh suggests, besides following the example of the Dutch in commercial enterprise, low duties, and marine architecture, raising the value of the English coins within the kingdom higher than in other countries for the purpose of keeping money at home.

He seems to have been much impressed with the importance of these remedies of his for the smallness of English commerce. He reiterates them in different forms, with abundant statistics to support his case. Though his appeal obtained no response from King James, it is well known that the latter part of the century saw an increase of English commerce, the English copying some features of the Dutch system, and that by the eighteenth century they had surpassed their teachers.

\title{
Old Monetary Problems
}

Among the recent acquisitions of the Society is a bulky Latin volume which throws an interesting light on the difficulties which beset the business men of earlier days. It was printed in $\mathrm{I} 59 \mathrm{I}$ at Colonia Agrippinae (Cologne) and its crowded title page may be freely translated as follows: "Two Books on Money and Monetary Problems, the first dealing with the Art of Coinage and the second with Monetary Problems, to which are added Various Useful Tracts together with Opinions and Annotations, by authors both ancient and modern who have discussed Money, its Value, Alloy, Weight, Power, Alteration, Variation, Counterfeiting, and the like." The author and editor, Renerus Budelius, was "prefect of moneys" under the Elector Ernest of Cologne.

Apart from the treaties on coinage, embellished with numerous wood-cuts and tables, which the author tells us he undertook as a necessary preliminary to his other studies, the greater part of the 
book's eight hundred handsomely-printed double-columned pages is devoted to discussion of the many perplexing problems which resulted from the confusion and instability that for centuries characterized the currencies of all Western Europe. When hundreds of petty sovereigns and feudal lords exercised the right of coining money, of changing its weight or fineness to suit their own purposes, and of raising or lowering the "prices" of some coins in terms of the others, many disputes were bound to arise in connection with contracts extending over a period of time. Could a debtor who had promised to pay gold meet his obligation by tendering silver? Was a creditor obliged to accept payment in coins of small denomination? Must the debtor repay according to the intrinsic value (metallic content) of money at the time the contract was made? Must a criminal pay his fine according to the intrinsic value of money at the time the statute imposing the penalty was passed? How about legacies under analogous circumstances? Was a contract for payment in coins of specified weight and fineness valid? Suppose the specified coins were no longer to be had? With these and more intricate problems the ablest jurisconsults wrestled for generations, and the pros and cons of their discussions are here set forth at considerable length.

More than half of the volume is occupied by the "Various Useful Tracts" which Budelius reprinted by way of supplement to his treatise, in order to set before his readers the more important authorities on the points he had discussed. The text of these, he tells us, had become so corrupted through the carelessness of copyists and printers that revision was sadly needed. Many of these selections had already been reprinted some twenty years earlier in a fat little volume edited by Matthew Boyss, "Tractatus Varii atque Utiles de Monetis," of which the Harvard Library possesses a copy. Boyss, a relative of Budelius, had dedicated the book to him. The principal change made by the latter, when he came to publish his own work, was the addition of a close translation into Latin of Bodin's "Réponse aux Paradoxes de M. de Malestroit," the most famous of early monetary tracts, together with the "Paradoxes" to which Bodin was replying. Both of these are rare and the Harvard Library has no copies of them. Among the other writers represented in the reprints it is interesting to note a president of the court at Malines and a professor of jurisprudence at the University of Louvain. All in all, this early forerunner of the modern book of "Readings" is not the least important part of the volume. 